\title{
Peripartal rumination dynamics and health status in cows calving in hot and cool seasons
}

\author{
S. Paudyal, ${ }^{*}$ F. Maunsell, $\dagger$ J. Richeson, ${ }^{*}$ C. Risco, $†$ A. Donovan, $†$ and P. Pinedo ${ }^{1}$ \\ *Department of Agricultural Sciences, West Texas A\&M University, Canyon 79016 \\ †Department of Large Animal Clinical Sciences, College of Veterinary Medicine, University of Florida, Gainesville 32611 \\ ‡Department of Animal Sciences, Colorado State University, Fort Collins 80523
}

\section{ABSTRACT}

Our objective was to evaluate the effect of season of calving, associated with variable levels of heat stress, on the dynamics of rumination during the prepartum period and early lactation of cows that were healthy or affected by peripartal health disorders. Three weeks before the estimated due date, 210 multiparous Holstein cows at the University of Florida Dairy Unit were affixed with a neck collar containing rumination loggers, providing rumination time (RT) in 2 -h periods. One blood sample was collected in a subpopulation of cows $(\mathrm{n}=76)$ at 12 to $48 \mathrm{~h}$ postcalving to assess metabolic status by determining serum calcium, nonesterified fatty acid, and $\beta$-hydroxybutyrate concentrations. The occurrence of peripartal health disorders (dystocia, clinical ketosis, clinical hypocalcemia, metritis, and mastitis) was assessed by University of Florida veterinarians and trained farm personnel. We analyzed the dynamics of daily $\mathrm{RT}$ over \pm 14 d relative to parturition in cows that were healthy or affected by specific health disorders by season of calving [hot season, June to September $(\mathrm{n}=77)$; cool season, November to April ( $\mathrm{n}=$ 118)] using repeated measures analysis and comparison of least squares means at different time points relative to calving. Rumination was consistently reduced on the day of calving in both healthy and sick cows in both the hot and cool seasons. Only hot-season calvings had shorter average daily RT prepartum and postpartum in cows affected by severe negative energy balance and subclinical ketosis. Dystocia during the hot season was associated with shorter daily RT prepartum; for coolseason calvings, cows with dystocia had reduced RT postpartum. We also observed reduced RT in cows with ketosis prepartum and postpartum in both the hot and cool seasons. Daily RT was reduced postpartum in cows with hypocalcemia and mastitis that calved during the

Received March 22, 2016.

Accepted July 16, 2016.

${ }^{1}$ Corresponding author: pablo.pinedo@colostate.edu cool season, and it was shorter in cows with metritis in both the hot and cool seasons. Our results indicated that the effect of heat stress on changes in rumination patterns around calving for sick cows depends on the specific health disorder or metabolic condition.

Key words: rumination, heat stress, disease

\section{INTRODUCTION}

Early detection of the signs of disease is key to successful health programs in dairy cows. An efficient health monitoring system is most crucial during the transition period, which is the most critical time for cow health and survival and for the profitability of the lactation. Endocrine changes at calving and drastic metabolic adjustments to support milk synthesis result in negative energy balance and immune suppression (Goff, 2004; Burton et al., 2005; Hammon et al., 2006). Consequently, a substantial proportion of cows are affected by disease around the time of calving, and most health disorders occur in the first 30 DIM (LeBlanc et al., 2006; LeBlanc, 2010; Vergara et al., 2014). In recent decades, the average US dairy herd size has been increasing consistently, resulting in less labor available per cow. Thus, the regular systematic evaluation of clinical parameters in animals at risk of disease is important to ensure herd health and select animals for clinical examination.

Rumination behavior has been suggested as an indicator of rumen condition and overall health (Welch and Smith, 1972; Herskin et al., 2004), although the process is influenced by many variables, including nutritional factors, such as digestibility of the feed, NDF intake, dietary composition, and forage quality (Welch and Smith, 1970; Beauchemin, 1991). Devices effective at measuring rumination by differentiating specific movements and sounds have been recently developed (Kononoff et al., 2002; Schirmann et al., 2009; Braun et al., 2013). The Hr-Tag rumination monitoring system (SCR Engineers Ltd., Netanya, Israel) provides output data for rumination time (RT), intervals between re- 
gurgitation of boluses, and chewing rate (Schirmann et al., 2009). The system has been validated in heifers, calves, and dairy cows (Schirmann et al., 2009; Burfeind et al., 2011), and associations between rumination behavior and calving events, peripartal metabolic status, and uterine diseases have been reported (Soriani et al., 2012; Calamari et al., 2014; Liboreiro et al., 2015). However, the effect of heat stress on the magnitude of changes in RT during the early stages of disease during the prepartum and early lactation periods has not been extensively explored. Summer heat is a significant stressor affecting dairy cows in the United States (St-Pierre et al., 2003), and direct negative effects on milk yield, health, and reproduction have been well documented (Jordan, 2003; West, 2003; de Vries and Risco, 2005). We were interested in the effect of heat stress on rumination dynamics around parturition in cows with peripartal health disorders. Our objective was to evaluate the effect of heat stress on RT during the prepartum and early lactation periods in cows that were healthy or affected by peripartal health disorders.

\section{MATERIALS AND METHODS}

\section{Animals and Farm Management}

The study was conducted in accordance with the guidelines for animal research and with the approval of the University of Florida Institutional Animal Care and Use Committee. The initial study population consisted of 210 multiparous Holstein cows enrolled $21 \mathrm{~d}$ before expected calving, from November 2013 to October 2014. From these, 205 cows successfully calved and completed the study. Cows were housed at the University of Florida Dairy Unit (Gainesville), which milked approximately 500 Holstein cows twice daily with a rolling herd average of approximately $10,000 \mathrm{~kg} / \mathrm{cow}$.

Dry cows were moved from a far-off dry-period pen to a prepartum pen 21 to $28 \mathrm{~d}$ before their expected calving. Prepartum housing consisted of a tunnelventilated barn with sprinklers over the feed bunk. The barn had a housing capacity of 12 cows (approximately $350 \mathrm{~m}^{2}$ with sand bedding) and $9 \mathrm{~m}$ of feed bunk space. The diet fed during the prepartum study period is described in Table 1. Feed was delivered once a day at approximately $0830 \mathrm{~h}$ and was pushed up 4 times a day between feedings. Cows were monitored by farm employees every $2 \mathrm{~h}$ for signs of calving and were moved out of the prepartum pen within $3 \mathrm{~h}$ after calving.

From d 0 to 2 postpartum, cows were housed in a hospital barn, consisting of an open hospital facility on a deep sand-bedded pack, measuring approximately $560 \mathrm{~m}^{2}$. An open-sided barn provided shade over 297 $\mathrm{m}^{2}$ of the bedded pack, and shade cloth provided shade over the feed bunk and water troughs. Cooling was provided by fans over the bedded pack and by sprinklers and fans over the feed bunk and water troughs. Group size ranged from 11 to 31 cows, and there was $19.5 \mathrm{~m}$ of feed bunk space. Cows in the hospital barn were fed the postpartum TMR, which is described in Table 1.

At $3 \mathrm{~d}$ postpartum, healthy cows were moved to the main lactating herd and kept in 2-row sand-bedded freestall barns equipped with headlocks. Cows that were sick on d 3 postpartum were moved to the lac-

Table 1. Ingredient and nutrient composition of pre- and postpartum diets (DM basis)

\begin{tabular}{|c|c|c|}
\hline \multirow[b]{2}{*}{ Item } & \multicolumn{2}{|c|}{ Diet } \\
\hline & Prepartum & Postpartum \\
\hline \multicolumn{3}{|l|}{ Ingredient (\%) } \\
\hline Grass hay & 21.3 & - \\
\hline Corn-sorghum silage & 52.2 & - \\
\hline Corn silage & - & 35.7 \\
\hline Rye grass-triticale silage & - & 9.5 \\
\hline Brewer's grains & 13.0 & 9.5 \\
\hline Citrus pulp & 6.1 & 7.1 \\
\hline Corn grain & - & 11.9 \\
\hline Whole cottonseed & - & 4.8 \\
\hline Canola meal & - & 8.6 \\
\hline Soybean meal, $47 \%$ CP & - & 7.1 \\
\hline StearoLac $^{1}$ & - & 1.0 \\
\hline Postpartum mineral supplement & - & 4.8 \\
\hline Prepartum mineral supplement & 2.2 & - \\
\hline Bio-Chlor $^{2}$ & 5.2 & - \\
\hline \multicolumn{3}{|l|}{ Nutrient profile } \\
\hline $\mathrm{NE}_{\mathrm{L}}^{3}(\mathrm{Mcal} / \mathrm{kg})$ & 1.54 & 1.72 \\
\hline $\mathrm{CP}(\%)$ & 14.1 & 17.6 \\
\hline $\operatorname{NDF}(\%)$ & 44.1 & 33.6 \\
\hline $\operatorname{ADF}(\%)$ & 25.2 & 22.0 \\
\hline Starch $(\%)$ & 19.3 & 24.0 \\
\hline Ether extract (\%) & 3.9 & 5.5 \\
\hline $\mathrm{Ca}(\%)$ & 0.63 & 0.79 \\
\hline $\mathrm{P}(\%)$ & 0.34 & 0.42 \\
\hline $\operatorname{Mg}(\%)$ & 0.44 & 0.41 \\
\hline $\mathrm{K}(\%)$ & 1.19 & 1.57 \\
\hline $\mathrm{Na}(\%)$ & 0.15 & 0.54 \\
\hline $\mathrm{Cl}(\%)$ & 0.87 & 0.55 \\
\hline $\mathrm{S}(\%)$ & 0.36 & 0.22 \\
\hline DCAD $(\mathrm{mEq} / \mathrm{kg})$ & -110 & 340 \\
\hline $\mathrm{Fe}(\mathrm{mg} / \mathrm{kg})$ & 143.26 & 165.20 \\
\hline $\mathrm{Zn}(\mathrm{mg} / \mathrm{kg})$ & 60.52 & 66.40 \\
\hline $\mathrm{Cu}(\mathrm{mg} / \mathrm{kg})$ & 14.11 & 13.72 \\
\hline $\mathrm{Mn}(\mathrm{mg} / \mathrm{kg})$ & 42.44 & 55.67 \\
\hline $\mathrm{Se}(\mathrm{mg} / \mathrm{kg})$ & 0.45 & 0.40 \\
\hline $\mathrm{Co}(\mathrm{mg} / \mathrm{kg})$ & 0.74 & 0.24 \\
\hline $\mathrm{I}(\mathrm{mg} / \mathrm{kg})$ & 0.50 & 0.67 \\
\hline Vitamin A (IU/kg) & 10,560 & 7,040 \\
\hline Vitamin D (IU/kg) & 3,300 & 1,320 \\
\hline Vitamin E (IU/kg) & 191,400 & 62,260 \\
\hline
\end{tabular}

${ }^{1}$ StereoLac energy supplement (Energy Feeds International, San Leandro, CA) contains hydrolyzed vegetable oil.

${ }^{2}$ Bio-Chlor (Arm \& Hammer Animal Nutrition, Princeton, NJ) contains the following (DM basis): $48.6 \% \mathrm{CP}, 13.5 \%$ starch, $2.07 \% \mathrm{Mg}$, $1.22 \% \mathrm{~K}, 1.49 \% \mathrm{Na}, 3.60 \% \mathrm{~S}$, and $9.09 \% \mathrm{Cl}$.

${ }^{3}$ Calculated at 11 and $19 \mathrm{~kg}$ of $\mathrm{DM} / \mathrm{d}$ for the pre- and postpartum diets (CPM-Dairy version 3.0.8.1; https://cahpwww.vet.upenn.edu/ doku.php/software:cpm:start). 
tating herd after illness had resolved and any milkwithholding period had elapsed. Freestall barns had fans with misters and sprinklers over the feed bunk. Stocking density in the barns that housed cows in early lactation ranged from 80 to $92 \%$. Feed bunk space at $100 \%$ stocking density was $61 \mathrm{~cm} /$ head. Lactating cows were fed a TMR (Table 1) formulated to meet or exceed the requirements of lactating cows weighing $\sim 680 \mathrm{~kg}$ and producing $45 \mathrm{~kg}$ of $3.5 \% \mathrm{FCM}$ as recommended by the National Research Council (NRC, 2001). Feed was delivered twice a day at approximately 0600 and 1500 $\mathrm{h}$, and feed was pushed up twice a day between feedings. Cows were milked twice daily at 0600 and 1800 $\mathrm{h}$, and individual milk yield was recorded at each milking (Afikim, Kibbutz Afikim, Israel). Sprinklers and misters for all housing areas were activated when the environmental temperature rose above $18^{\circ} \mathrm{C}$. For the hospital and freestall barns, fans were activated when the environmental temperature rose above $12.6^{\circ} \mathrm{C}$; fans in the prepartum barn were always operating. Fresh potable water was available to all cows. Cows were vaccinated and treated for common diseases according to standard operating procedures developed with veterinarians from the University of Florida College of Veterinary Medicine.

\section{Experimental Procedures}

Health Monitoring. Cows' health was monitored by University of Florida veterinarians and trained farm staff. Physical examinations were not routinely performed on prepartum cows, but they were observed daily by trained farm staff for any indication of clinical disease. Calving-related events, such as dystocia and twins, were recorded by farm personnel. All cows went through a routine postpartum health evaluation at $\mathrm{d} 4$, 7, and 12 after calving. This evaluation was performed immediately after the morning milking and included assessment of attitude, rectal temperature, rectal palpation, examination of vaginal discharge, udder inspection, assessment of urine ketone bodies (Ketostix, Bayer Corporation Elkhart, IN) and investigation for displaced abomasum. Automatic health reports were created for every milking event based on individual milk production and milk component levels provided by the AfiMilk meters (Afikim). Cows with deviations from established ranges in at least 2 parameters (milk and milk components) in 2 consecutive milkings were automatically sorted for a complete health check. Definite diagnoses of diseases in the study were made by University of Florida veterinarians or trained farm personnel based on University of Florida Dairy Unit standard operating procedure definitions developed at the University of Florida College of Veterinary Medi- cine. Peripartal health disorders under analysis (dystocia, clinical ketosis, clinical hypocalcemia, metritis, and mastitis) were assessed by University of Florida veterinarians and trained farm personnel. The disorders were defined as follows: dystocia = calving that is not progressing (no change in labor status 45-60 min since the last observation) and that requires significant assistance ( 2 people); clinical ketosis = negative milk deviation, off milk, licking pipes, unsteady, nervous attitude, strong positive in urinalysis (Ketostix); clinical hypocalcemia $=$ down cow or cow unsteady from before calving to 1 or $2 \mathrm{~d}$ after calving with no other abnormal physical findings (especially mastitis or metritis). Head may be turned into the flank or may be extended, and ears are cold and nose is dry; metritis = cow presenting with watery, fetid vaginal discharge that is dark red to brown in color within 21 DIM; and mastitis = presence of significant flakes and clumps in milk. Udder quarter may be hot, swollen, hard, and painful with watery or serous secretion. Fever was defined as rectal temperature $>39.5^{\circ} \mathrm{C}$.

Blood samples were collected from a subpopulation of cows $(\mathrm{n}=76 ; 49$ and 27 for hot and cool seasons, respectively) at 12 to $48 \mathrm{~h}$ postcalving for assessment of metabolic status through determination of serum calcium, nonesterified fatty acids, and BHB concentrations. Cows were considered to be in severe negative energy balance with a serum nonesterified fatty acid concentration $>0.5 \mathrm{mmol} / \mathrm{L}$; positive for subclinical ketosis with a serum $\mathrm{BHB} \geq 1.4 \mathrm{mmol} / \mathrm{L}$; and affected by subclinical hypocalcemia with a serum calcium concentration $<8.0 \mathrm{mg} / \mathrm{dL}$ but no clinical signs (Goff, 2004; LeBlanc et al., 2006; Chapinal et al., 2011). A cow was considered healthy if she was not affected by any health disorder during the study period $(-14 \mathrm{~d}$ to $14 \mathrm{~d}$ relative to calving).

Recording of Rumination and Activity Data. A previously described and validated (Schirmann et al., 2009) rumination monitoring system (Hr-Tag; SCR Engineers Ltd.) was affixed to the neck of each study cow at enrollment (d 21 relative to estimated due date). Because our analyses considered raw rumination data and we did not use the algorithms provided by the system's software, we did not need an extended period $(7$ to $10 \mathrm{~d})$ to establish a rumination baseline for the study cows. Rumination was recorded in minutes per 2-h intervals, and data were transmitted using radio frequency and captured by long-distance antennas on the milking parlor roof and close to the prepartum barn. Information was summarized as total rumination minutes per day for the statistical analyses.

Temperature and Humidity Data. The climate was classified as subtropical, with average ambient temperatures for the summer months (June to August) 
ranging from $21.1^{\circ} \mathrm{C}$ (minimum) to $32.2^{\circ} \mathrm{C}$ (maximum), with a relative average humidity of $92.9 \pm 15 \%$. Two calving seasons were determined for the study: hot, from June 1 to September $30(\mathrm{n}=77)$; and cool, from November 1 to April $30(\mathrm{n}=118)$. Cows calving during May and October $(\mathrm{n}=10)$ were removed from the analysis. Daily temperature and humidity data for the study period were obtained from the archives of the weather channel (Weather Underground, 2014) for a weather station $15 \mathrm{~km}$ from the farm (Gainesville Regional Airport, Gainesville, FL). Average daily temperature and average daily humidity were used to calculate a temperature-humidity index (THI) for each day of the study using the formula $\mathrm{THI}=\mathrm{TD}$ $\left({ }^{\circ} \mathrm{F}\right)-[0.55-(\mathrm{RH} / 100) \times 0.55] \times(\mathrm{TD}-58)$, where $\mathrm{TD}=$ daily temperature and $\mathrm{RH}=$ relative humidity (Bohmanova et al., 2007). A cut-off value of 76.2 was considered to categorize the weather as hot and cool based on a previous report by Benzaquen et al. (2007) from a nearby location.

\section{Statistical Analysis}

Data were organized in spreadsheets (Excel 2013; Microsoft, Redmond, WA), and all subsequent analyses were performed using SAS (version 9.4; SAS Institute Inc., Cary, NC). Data available for the analyses included a study population of 195 cows that calved during the 2 defined seasons (hot season and cool season). The effect of disease on daily RT was assessed by season of calving during 2 periods relative to parturition (prepartum $=\mathrm{d}-14$ to $\mathrm{d}-1$; and postpartum $=\mathrm{d} 0$ to $\mathrm{d} 14$ ) using repeated measures analysis (REPEATED statement for PROC MIXED) considering an autoregressive covariance structure. Differences in daily RT by season of calving and health status were also determined by comparing least squares means (LSMEANS statement from PROC GLM) at multiple data points $(-14 \mathrm{~d} ;-7$ d, $0 \mathrm{~d}, 7 \mathrm{~d}$, and $14 \mathrm{~d}$ relative to calving). Effects were deemed significant when $P \leq 0.05$. Statistical tendency was defined as $0.05<P \leq 0.10$. It was expected that some cows would present with concomitant metabolic conditions and health disorders (Ospina et al., 2010), but to maintain a smaller number of disease categories, each condition was analyzed separately.

\section{RESULTS}

\section{Climatic Data}

During the study period, the ambient THI ranged from 41 to 87 units. The highest THI was recorded in August, and the lowest in January. Overall, 97 days had a THI $>76.2$ (our cutoff value for heat stress). The distribution of these 97 days by month was 19, 30, 29, and 19 for June, July, August, and September, respectively. The monthly average THI was $>76.2$ during 4 months of the study period (June to September), in agreement with our definition of the hot season (Figure 1).

\section{Rumination Activity in Healthy Cows}

The initial study population consisted of 210 multiparous Holstein cows, and 205 cows completed the study. Cows $(\mathrm{n}=10)$ that calved in May or October were removed from the analysis. Overall, 137 cows (hot season 55; cool season 82 ) were not affected by any of the health disorders included for analysis and were categorized as healthy. The average RT before calving $(\mathrm{d}-14$ to $\mathrm{d}-1)$ in healthy cows was $428 \pm 3.6 \mathrm{~min} / \mathrm{d}$ in the hot season vs. $447 \pm 2.8 \mathrm{~min} / \mathrm{d}$ in the cool season $(P<0.001)$. However, after calving (d 0 to d 14$)$, daily RT was not different for healthy cows calving in either season $(447 \pm 4.0 \mathrm{~min} / \mathrm{d}$ vs. $448 \pm 3.1 \mathrm{~min} / \mathrm{d})$.

At $\mathrm{d}-14$, healthy cows had average daily RT of 432 \pm 10.6 and $487 \pm 7.6 \mathrm{~min} / \mathrm{d}(P<0.002)$ during the hot and cool seasons, respectively. At $-7 \mathrm{~d}$, the average daily RT tended to be different for the hot and cool seasons $(426 \pm 9.6$ vs. $457 \pm 9.6 \mathrm{~min} / \mathrm{d} ; P=0.09)$, respectively. After parturition, daily RT increased from $329 \pm 12.4 \mathrm{~min} / \mathrm{d}$ (d 0) to $482 \pm 8.0 \mathrm{~min} / \mathrm{d}(\mathrm{d} 7$ ) and $493 \pm 8.8 \mathrm{~min} / \mathrm{d}$ (d 14) during the hot season and from $323 \pm 11.9 \mathrm{~min} / \mathrm{d}(\mathrm{d} 0)$ to $495 \pm 7.6 \mathrm{~min} / \mathrm{d}(\mathrm{d} 7)$ and $489 \pm 7.8 \mathrm{~min} / \mathrm{d}$ (d 14) during the cool season, but we established no differences between seasons for $\mathrm{d} 0, \mathrm{~d} 7$, or $\mathrm{d} 14$. The average $( \pm \mathrm{SE})$ daily RT by month of study at $\mathrm{d}-14, \mathrm{~d} 0$, and $\mathrm{d} 14$ for healthy cows are provided in Figure 1. The average RT in 2 -h periods for $\mathrm{d}-14$, $\mathrm{d}-7, \mathrm{~d} 0, \mathrm{~d} 7$, and $\mathrm{d} 14$, in healthy cows, by season of calving are presented in Figure 2. The 2-h RT varied over the course of each day, and was highest during the night (2000 h to $0400 \mathrm{~h}$ ). During the prepartum period, this nocturnal rise in RT occurred $2 \mathrm{~h}$ earlier for cows who calved in the cool season than for cows who calved in the hot season. Although we observed seasonal effects, we found a very weak correlation between daily THI and daily RT $(\mathrm{r}=-0.06 ; P<0.0001)$.

\section{Association Between Rumination Activity and Peripartal Health Disorders}

The number of cows (until $14 \mathrm{~d}$ postcalving) affected by dystocia, clinical hypocalcemia, ketosis, metritis, and mastitis were $6,7,30,31$, and 16 , respectively. For subclinical metabolic disorders, 44, 15, and 29 cows from the subpopulation of study cows $(\mathrm{n}=76)$ were 


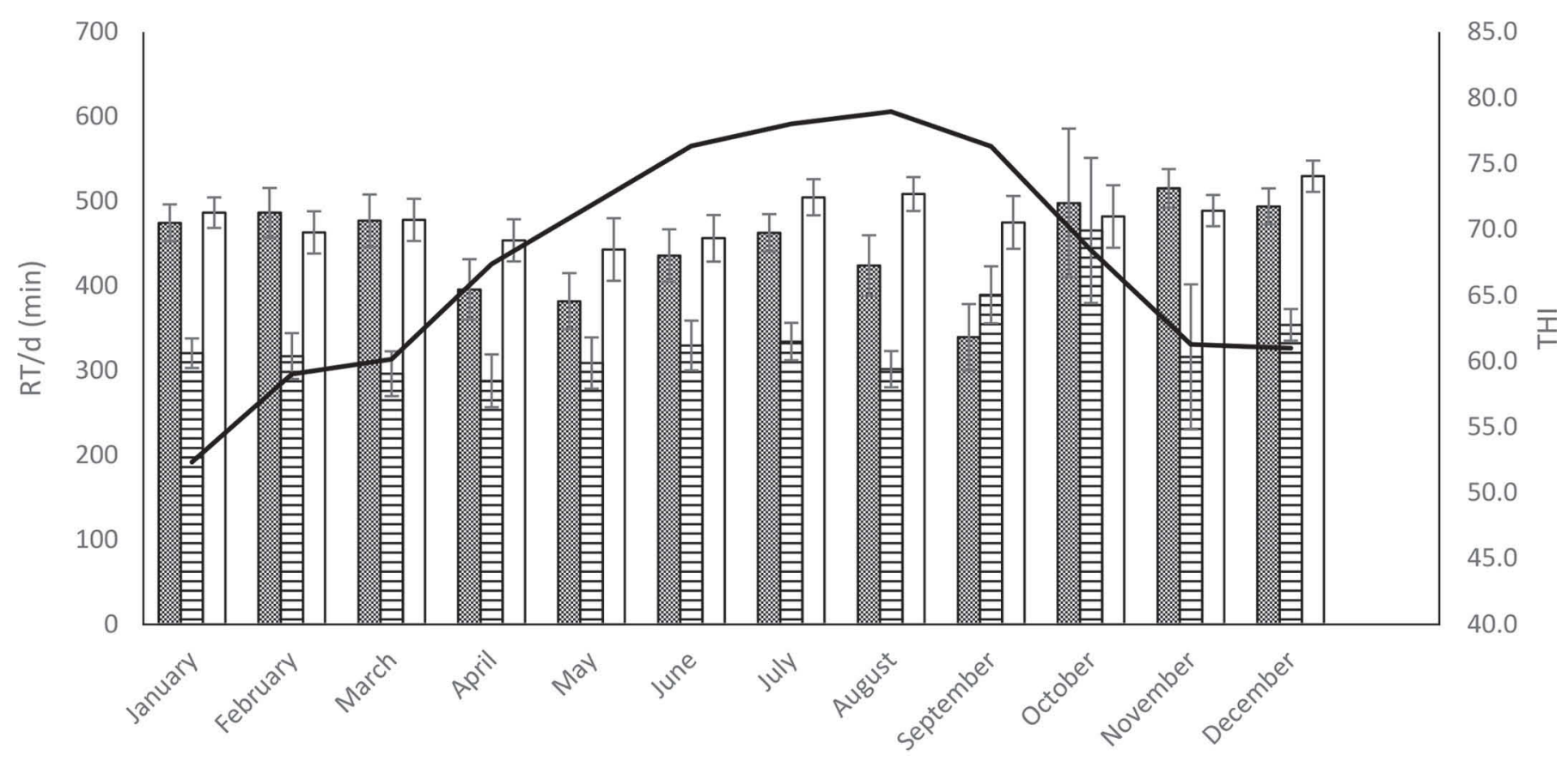

Month

एक्षा-14

Figure 1. Average (SE) daily rumination time (RT; min) and temperature-humidity index (THI) by month in healthy cows.

diagnosed with negative energy balance, subclinical ketosis, and subclinical hypocalcemia, respectively.

Cows with negative energy balance and subclinical ketosis during the hot season had lower average daily RT than healthy cows, but we did not observe this difference in cows that calved during the cool season (Figure 3 ). The daily RT for cows with subclinical hypocalcemia was similar to that of healthy cows during the hot season. However, during the cool season, RT after calving was lower in affected cows than in healthy animals.

Cows with dystocia in the hot season had a lower RT than unaffected cows during the prepartum period. However, we did not observe this effect during the cool season, where cows with dystocia had reduced RT postpartum (Figure 4). Cows with clinical ketosis had a lower RT pre- and postpartum in both the hot and cool seasons. Daily RT was reduced only postpartum in cows with clinical hypocalcemia in the cool season, and cows with metritis had reduced postpartum RT in both the hot and cool seasons. Cows with mastitis had reduced postpartum RT for cool season calvings (Figure 5).

We evaluated the average RT at specific time points relative to calving, and comparisons between cows with and without specific disease conditions, by season of calving, are presented in Table 2. At $-14 \mathrm{~d}$, cows with dystocia (hot season) and mastitis (cool season) had a significantly lower RT than healthy cows $(P=0.02$ and $P=0.03$, respectively). At d 0 , cows with dystocia and clinical ketosis had reduced RT relative to healthy cows ( $P=0.04$ and $P=0.02$, respectively) during the hot season. We observed significant reductions in RT at d 14 only in clinical ketosis (hot season; $P<0.001$ ), subclinical hypocalcemia (cool season; $P=0.009$ ), and clinical hypocalcemia cases (cool season; $P=0.0004$ ).

We found effects of season on RT at multiple time points when we examined this relationship for cows with and without health disorders (Table 2). At -14 $\mathrm{d}$, RT was shorter in the hot season than in the cool season for cows with and without dystocia $(P=0.028$ and $P=0.025$, respectively), and for cows without clinical hypocalcemia $(P=0.01)$, clinical ketosis $(P=$ $0.02)$, metritis $(P=0.02)$, and mastitis $(P=0.008)$. At d 0, RT was shorter during the cool season in cows without subclinical ketosis $(P=0.04)$. At d 14 , RT was shorter for cows with subclinical hypocalcemia in the hot season $(P=0.03)$ and for cows without subclinical ketosis $(P=0.03)$ and with subclinical hypocalcemia $(P=0.02)$ in the cool season. 
PAUDYAL ET AL.
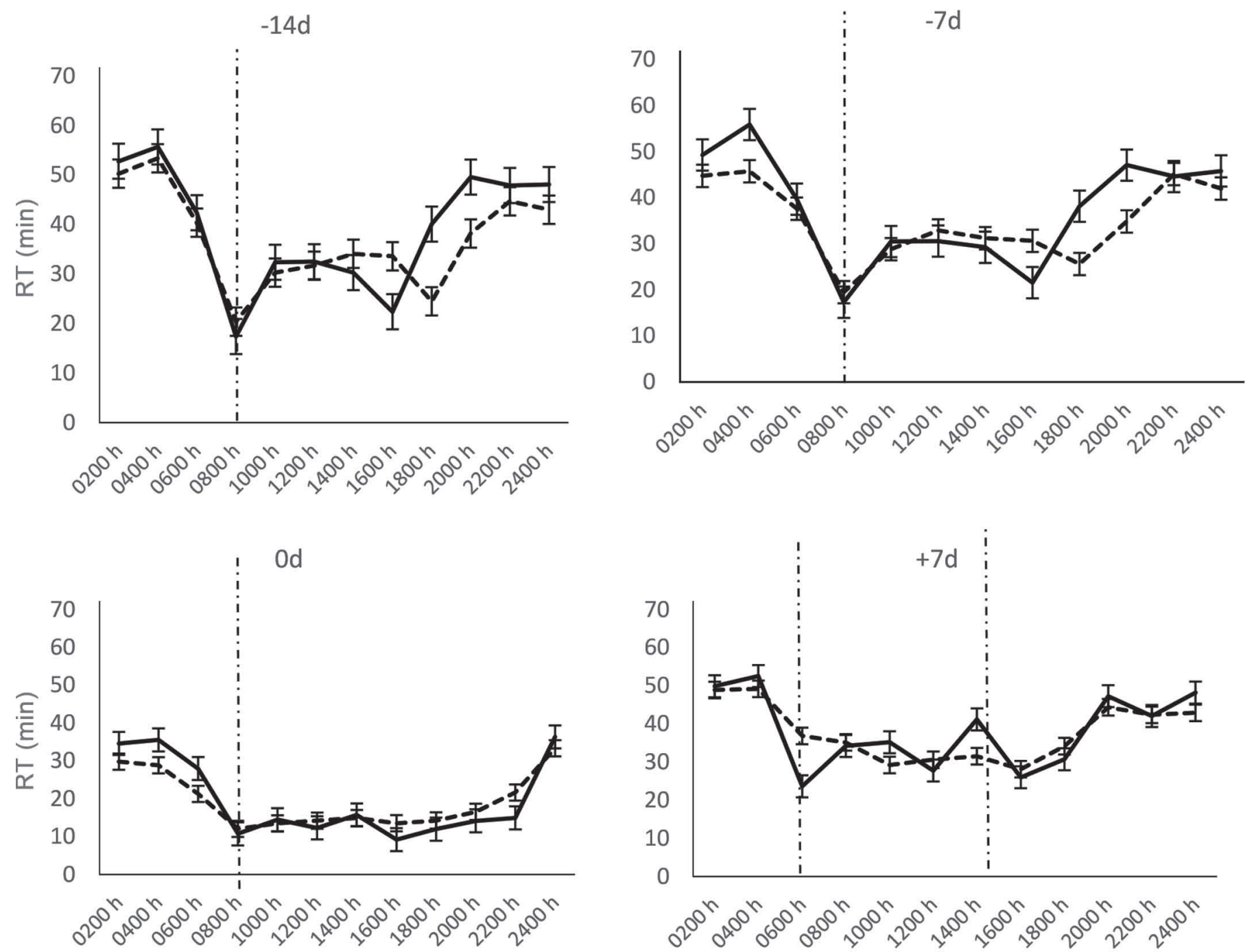

Time of day

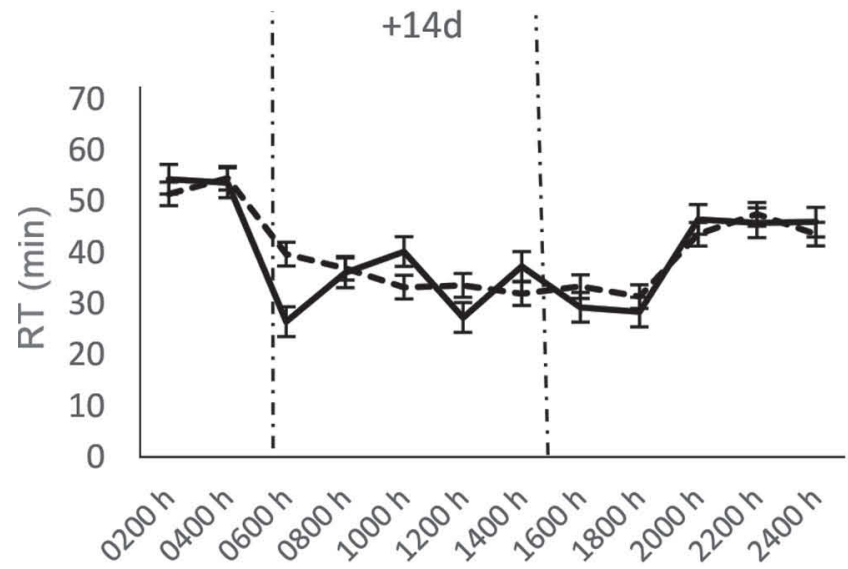

Time of day

Figure 2. Average (SE) rumination time (RT; min) in 2-h intervals in healthy cows at d $-14,-7,0,7$, and 14 relative to calving during the hot season (dashed line) and the cool season (solid line). Vertical dashed lines indicate the approximate time of feed delivery. 

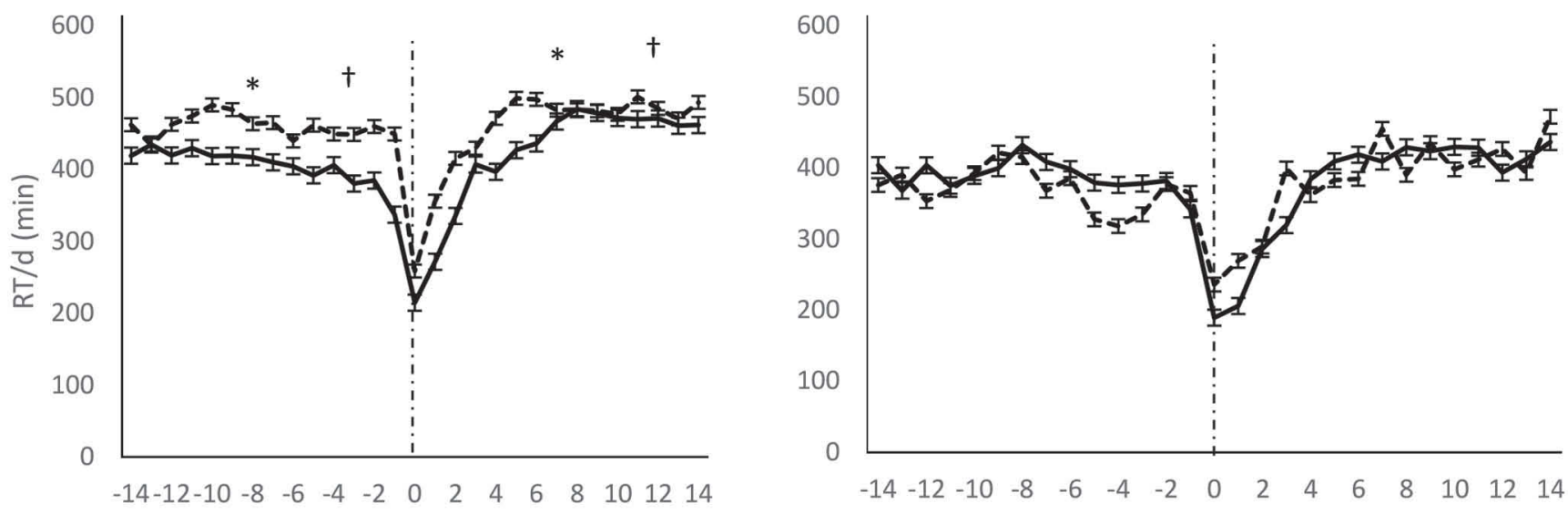

a

SCK $\quad b$

SCK
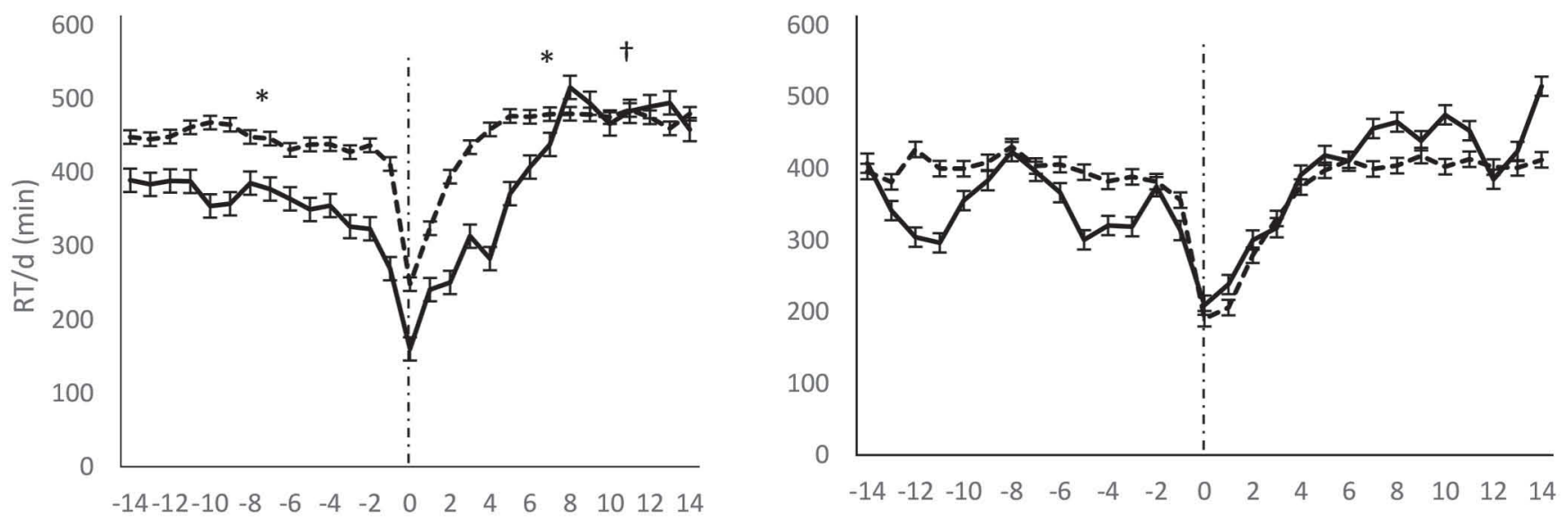

a
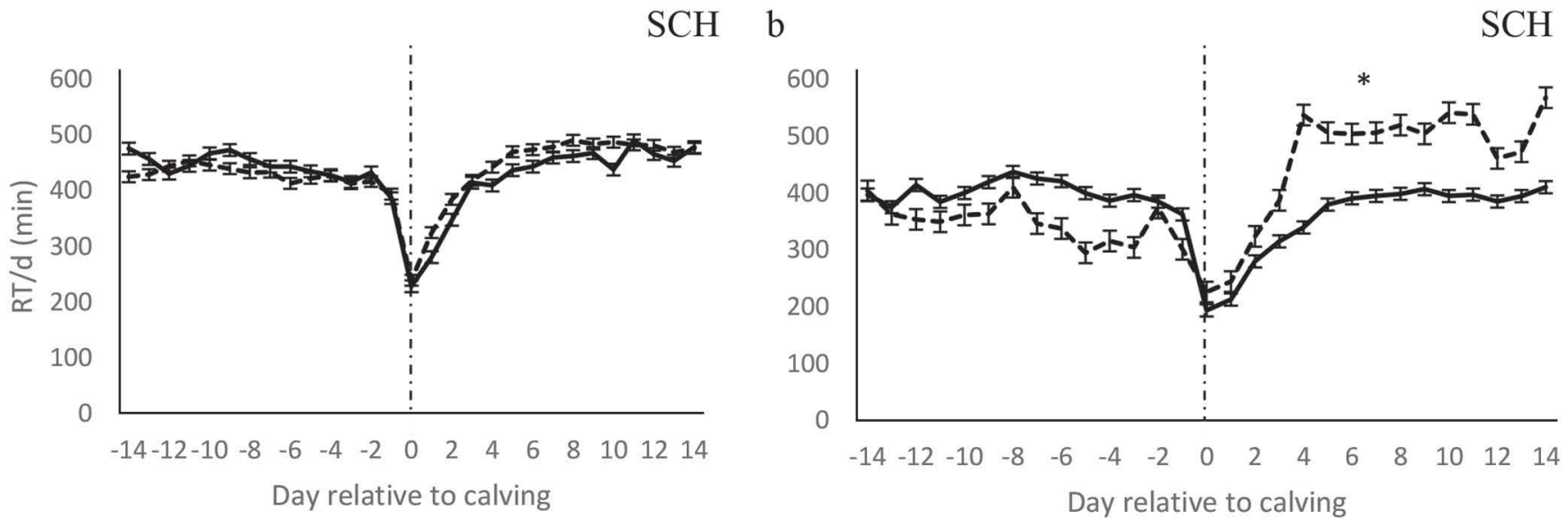

Figure 3. Variation of daily rumination time (RT) around calving in healthy cows (dashed line) versus cows with negative energy balance, subclinical ketosis, or subclinical hypocalcemia (NEB, SCK, or SCH; solid line) during (a) the hot season and (b) the cool season. Statistical significance for differences is provided by period ( $\mathrm{d}-14$ to -1 and d 0 to 14 relative to calving, indicated by a vertical dashed line). ${ }^{*} P<0.05$ for the effect of health status; $\dagger P<0.05$ for the effect of time $\times$ health status interaction. Values are presented as LSM \pm SE. 
PAUDYAL ET AL.

a

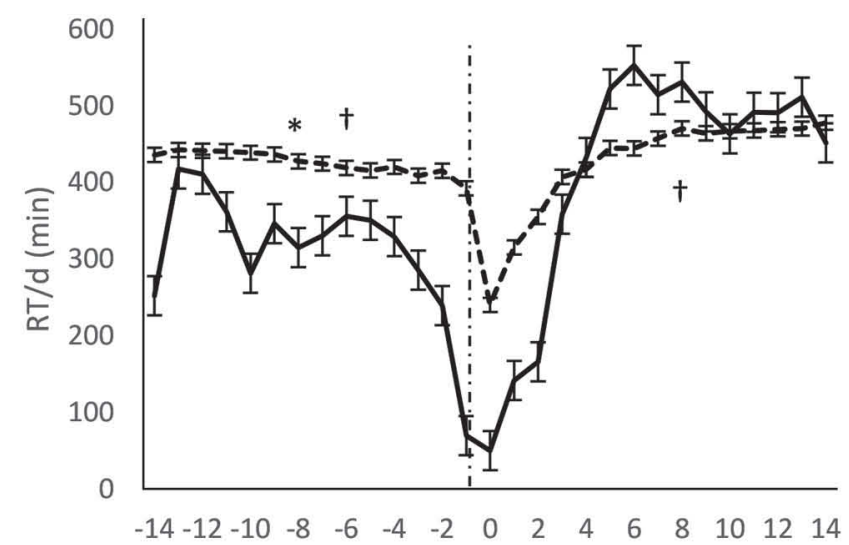

DYS b

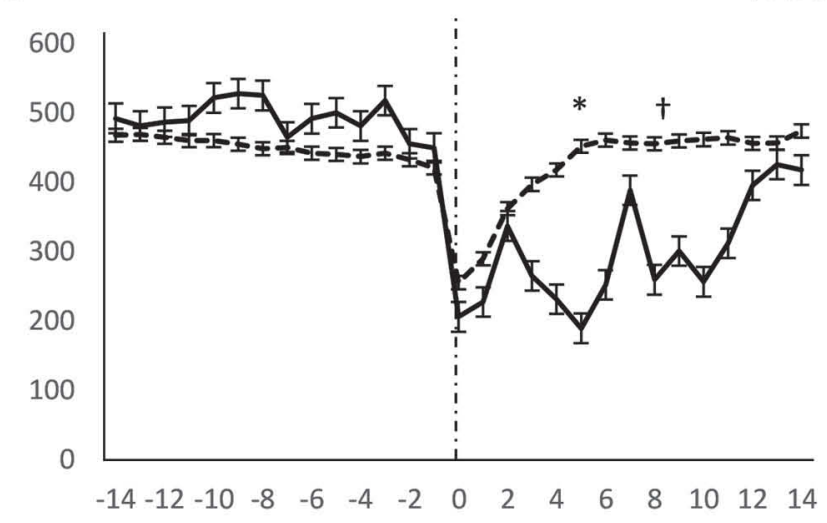

b

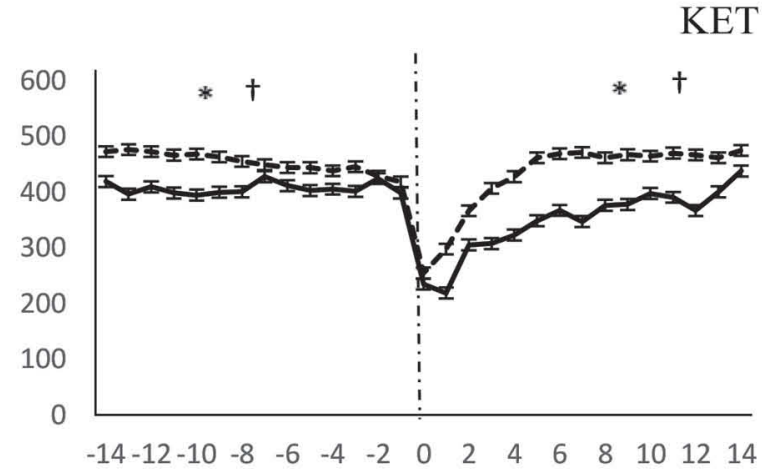

HYC

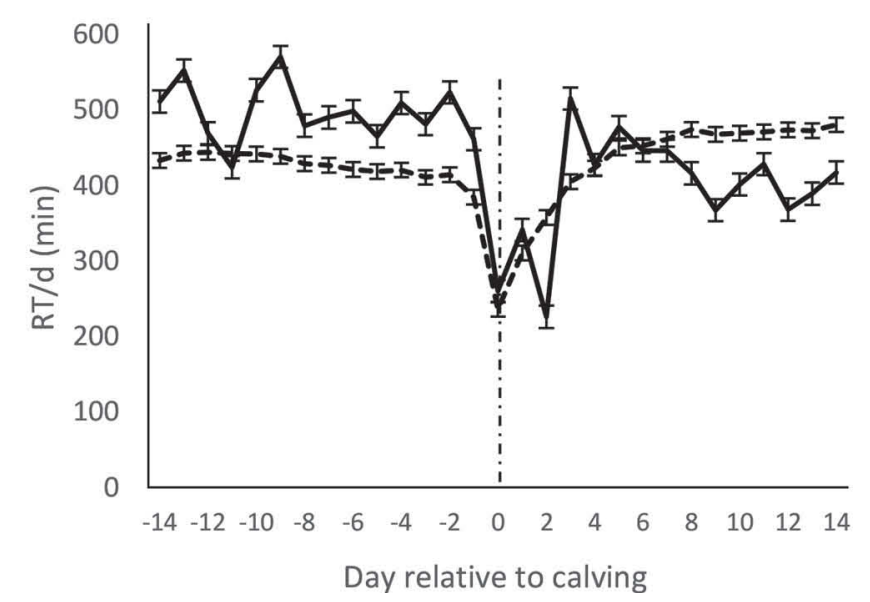

b

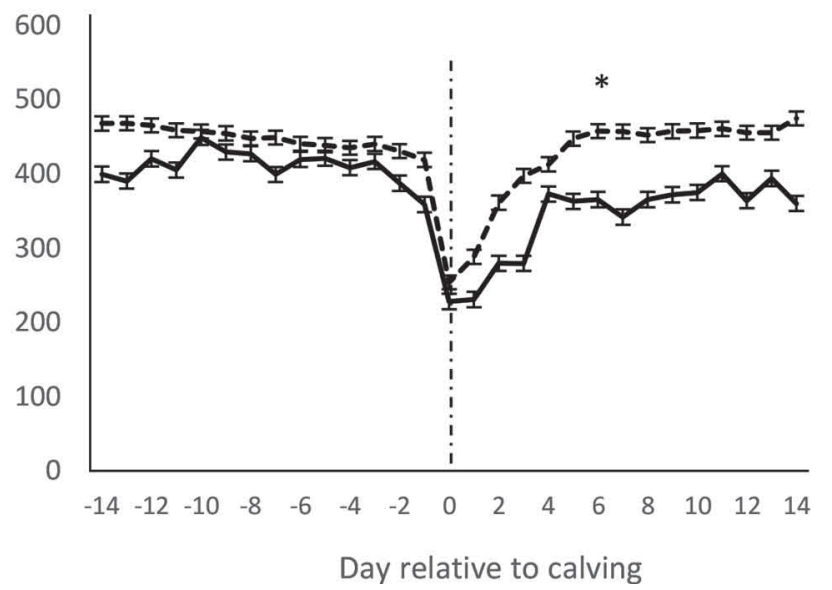

Figure 4. Variation of daily rumination time (RT) around calving in healthy cows (dashed line) versus cows with dystocia, clinical ketosis, or clinical hypocalcemia (DYS, KET, or HYC; solid line) during (a) the hot season and (b) the cool season. Statistical significance for differences is provided by period ( $\mathrm{d}-14$ to -1 and d 0 to 14 relative to calving, indicated by a vertical dashed line). ${ }^{*} P<0.05$ for the effect of health status; $\dagger P<0.05$ for the effect of time $\times$ health status interaction. Values are presented as $\mathrm{LSM} \pm \mathrm{SE}$.

\section{DISCUSSION}

The average RT we observed before calving (428 $\mathrm{min} / \mathrm{d}$ and $447 \mathrm{~min} / \mathrm{d}$ for the hot and cool seasons, respectively), and after calving (447 $\mathrm{min} / \mathrm{d}$ and 448 $\min / \mathrm{d}$ for the hot and cool seasons, respectively) were within the ranges reported in previous studies. Soriani et al. (2012) reported RT of $522 \mathrm{~min} / \mathrm{d}$ and $562 \mathrm{~min} / \mathrm{d}$ for pluriparous cows prepartum ( -20 to $-6 \mathrm{~d})$ and postpartum (15 to $-40 \mathrm{~d})$, respectively. These times 
were greater than those reported in our study, but excluded the days close to parturition, where a nadir in RT is expected. Closer to our values, Calamari et al. (2014) reported an average RT of $479 \mathrm{~min} / \mathrm{d}$ between -20 and $-2 \mathrm{~d}$ before calving, and Aikman et al. (2008) reported $477 \mathrm{~min} / \mathrm{d}$ and $623 \mathrm{~min} / \mathrm{d}$ for dry and lactating Holsteins. A recent study by Liboreiro et al. (2015) reported RT of 450 and $407 \mathrm{~min} / \mathrm{d}$ for prepartum (-17 to $-1 \mathrm{~d}$ ) and postpartum (0 to $17 \mathrm{~d}$ ) cows, respectively. Such variations in recorded RT can be explained by differences in feed ingredients, environmental conditions, period of lactation, and animal factors (Welch and Smith, 1970; Beauchemin, 1991; Beauchemin and Yang, 2005). Interestingly, Byscov et al. (2015) reported that about $32 \%$ of the variation in $\mathrm{RT}$ was related to differences in intake of forage NDF, starch, sugar, and the remaining fraction in individual cows and DIM, whereas $48 \%$ of the total variation in RT was found between cows. Unfortunately, as expected for a study that extended for several months, the characteristics of the TMR (particle size, composition) may have varied slightly across time, and such potential changes were not routinely recorded. As in preceding studies, RT in our study was consistently reduced around the day of parturition, likely a result of limited feed intake and calving-related behavior (Huzzey et al., 2005; Schirmann et al., 2013; Clark et al., 2015). However, because our data were summarized in 24-h intervals, a

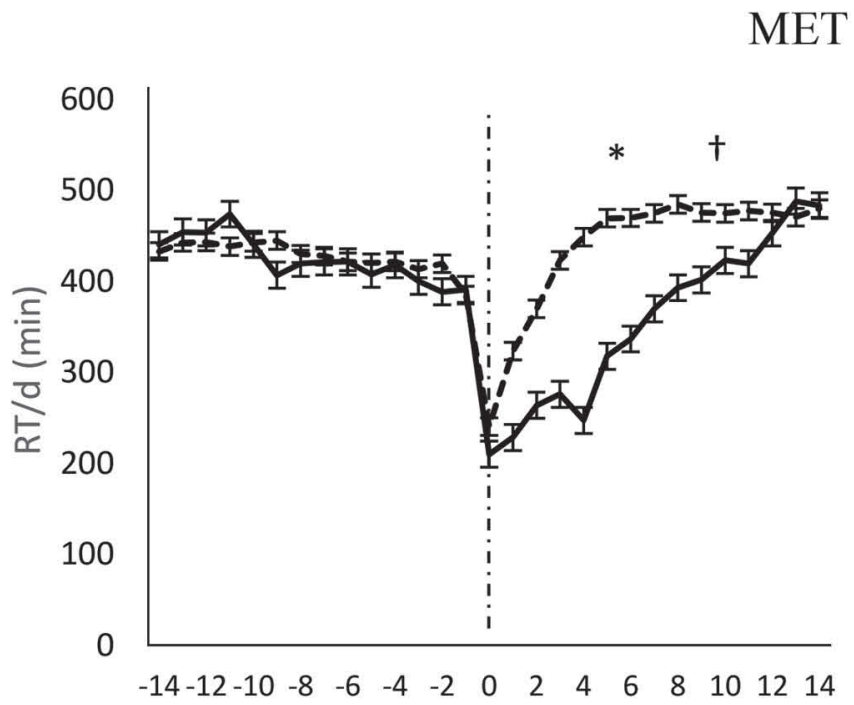

b

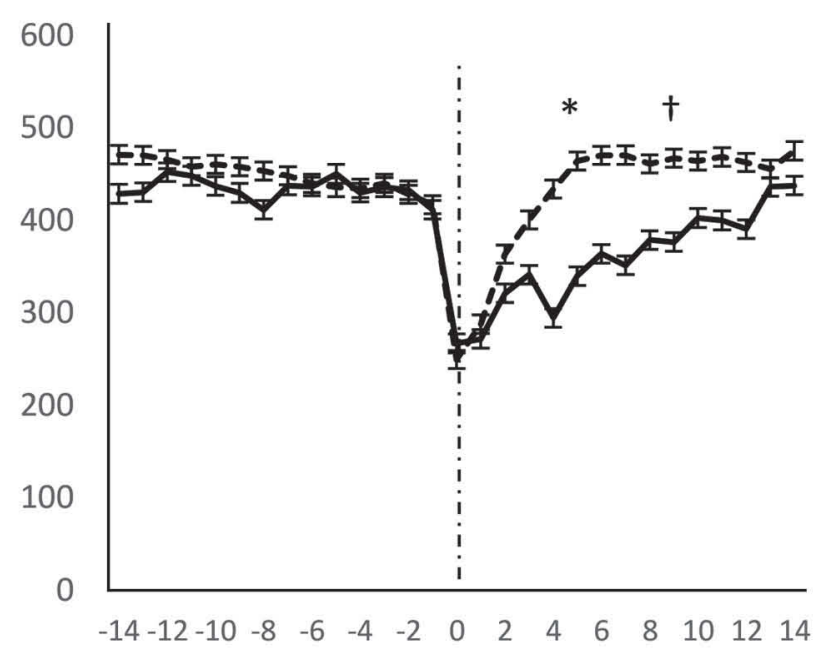

MAS b

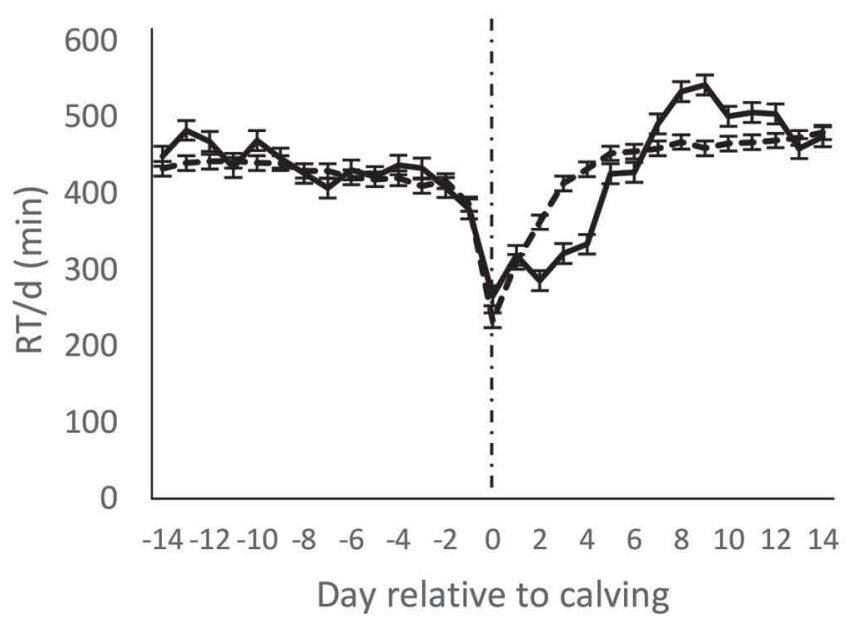

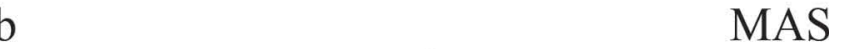

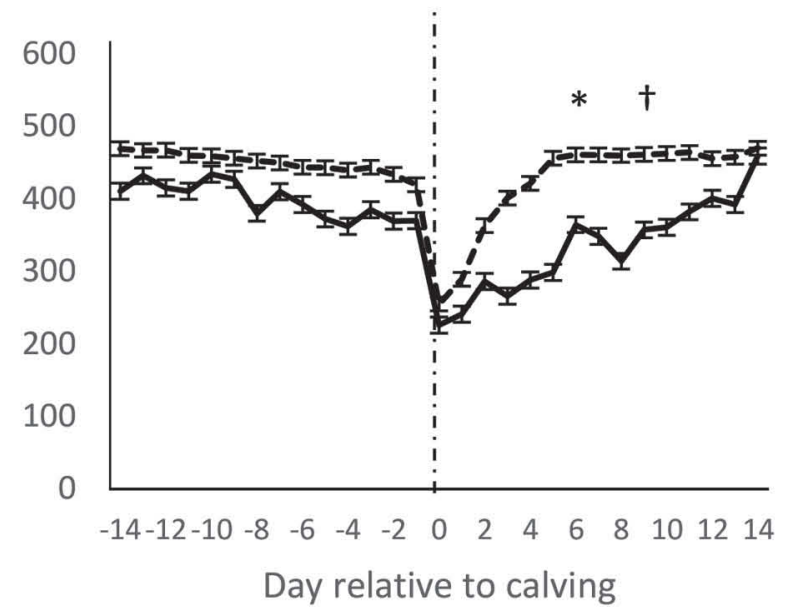

Figure 5. Variation of daily rumination time (RT) around calving in healthy cows (dashed line) versus cows with metritis or mastitis (MET or MAS; solid line) during (a) the hot season and (b) the cool season. Statistical significance for differences is provided by period (d -14 to -1 and d 0 to 14 relative to calving, indicated by a vertical dashed line). ${ }^{*} P<0.05$ for the effect of health status; $† P<0.05$ for the effect of time $\times$ health status interaction. Values are presented as LSM $\pm \mathrm{SE}$. 
information about RT around the exact time of parturition could not be derived.

In our study, 2-h RT fluctuated significantly during the day and across the time points under analysis. Such variation was expected and could be related to the time of feed delivery and pushing or the hourly THI fluctuation; cattle would be expected to have lower rumination during feed delivery and warmest hours of the day (Aikman et al., 2008). During the study period, feed for lactating cows was delivered twice a day at approximately $0600 \mathrm{~h}$ and $1500 \mathrm{~h}$ and pushed up twice a day between each feeding (Figure 2). The greatest RT values occurred during the night $(2000 \mathrm{~h}$ to $0400 \mathrm{~h})$, supporting the understanding that rumination increases when cows are at rest. On the study farm, the p.m. milking was finished around $0100 \mathrm{~h}$; in the summer, this time also coincided with the coolest period of the day. Our findings were in line with Soriani et al. (2012), who reported that the percentage of RT during the night in pluriparous cows was $62 \%$ and $57 \%$ before and after calving, respectively. Similarly, Clark et al. (2015) reported that the longest and most intensive rumination bouts occurred during the night, and Pahl et al. (2014) indicated maximum RT levels around 0200h and 0400h.

The THI has been widely used to estimate the magnitude of heat stress. In adult Holstein cows, the THI above which milk yield declines has been estimated at 72 to 77 (Johnson et al., 1963; Bohmanova et al., 2007), and the THI above which rectal temperature increases has been estimated at 78 (Dikmen and Hansen, 2009). During the study period, the monthly average THI was
$>76.2$ during the 4 months considered to be the hot season. Before calving (21-28 d before expected due date), study cows were moved to barns with cooling systems that may have reduced the effects of summer heat stress. In our study, in spite of the heat-abatement technologies in use, RT for summer calvings was lower during the prepartum period. Similarly, for specific time points in healthy cows, RT at d -14 was shorter in the hot season than in the cool season (432 vs. 487 $\min / \mathrm{d}$ ). Interestingly, the average daily RT postpartum of healthy cows in warm weather was not different from that recorded in cold weather. In agreement with the observed reductions in RT during the hot season, the coefficient of correlation for the daily THI and daily RT was negative but small, agreeing with Soriani et al. (2013), who also reported a negative correlation ( $\mathrm{r}=$ -0.32 ) between THI and RT.

Associations between rumination behavior and calving events, peripartal metabolic status, and uterine diseases have been reported (Schirmann et al., 2013; Calamari et al., 2014; Liboreiro et al., 2015). In our study, RT reductions in sick cows were more evident when complete periods were included in the repeated measures analysis (i.e., prepartum and postpartum), instead of specific time points (Table 2, Figures 3, 4 and 5), indicating that including more information across days may help detect RT changes associated with disease states. As expected (Ospina et al., 2010), some cows presented with concomitant metabolic conditions and health disorders. To maintain a lower number of disease categories, each condition was analyzed

Table 2. Average (SE) rumination time ( $\mathrm{min})$ at different times relative to calving $(\mathrm{d}-14,0$, and 14$)$ in cows with and without periparturient health disorders by calving season $(\mathrm{n}=195)$

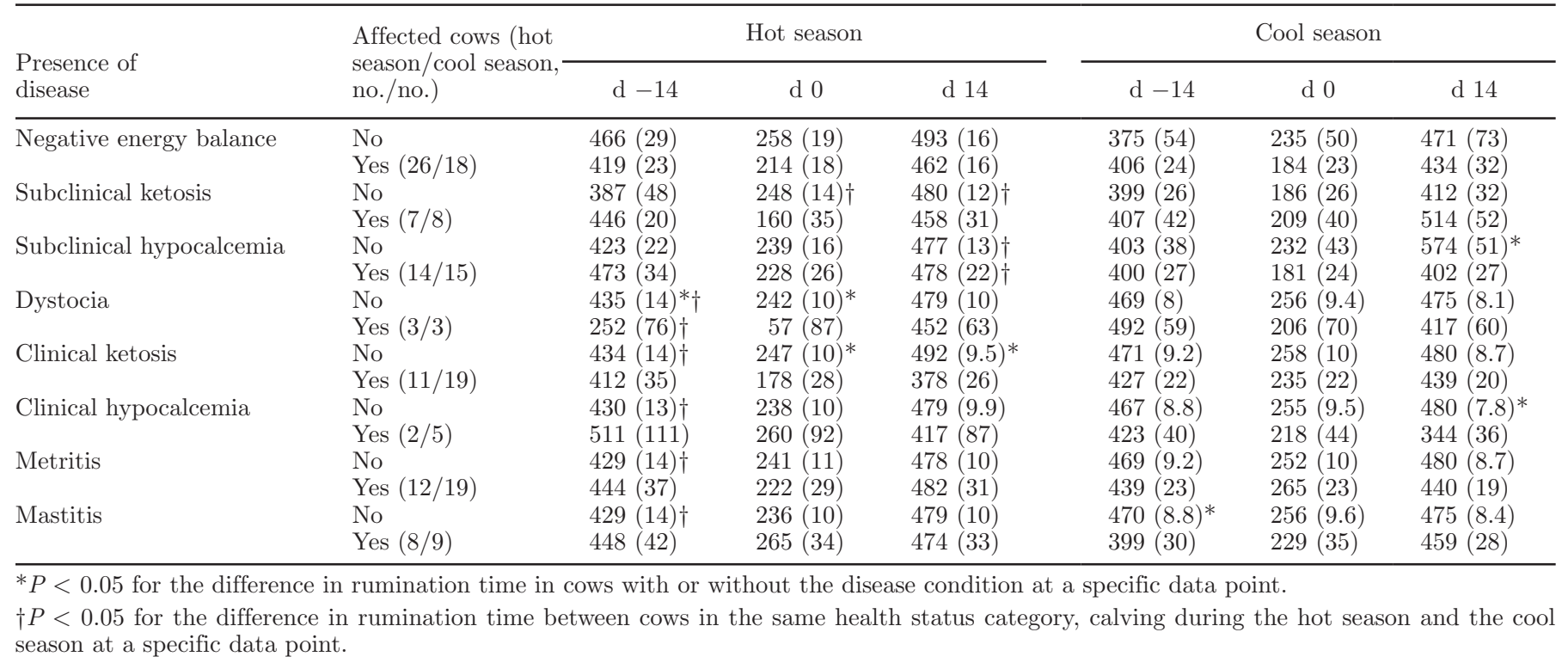


separately. However, cows affected by 2 simultaneous disorders may have had stronger alterations in RT than cows with only 1 problem.

Other studies have also considered repeated measures to detect differences between healthy and sick cows; however, measures of the potential for detection of differences in RT have been variable (Soriani et al., 2012; Calamari et al., 2014; Liboreiro et al., 2015). Although differences in RT between healthy and sick cows depended on the particular disease present, the period relative to calving, and the season, in most cases in our study, the average daily RT was higher in healthy animals than in sick animals, which can be explained by altered rumination and feeding during sickness (Liboreiro et al., 2015). This general pattern is in harmony with findings presented by Soriani et al. (2012), where cows grouped according to shorter RT before calving had higher incidence of clinical disease during the first days of lactation than cows with moderate or long RT. That study also reported that severe inflammation around parturition was associated with a slower increase in RT after calving. In addition, a higher proportion of cows with lower RT had subsequent clinical disease in early lactation than cows with higher RT ( $90 \%$ vs. $42 \%$ ). On the other hand, cows with reduced $\mathrm{RT}$ before calving maintained reduced RT after calving and had a greater frequency of disease than cows with greater RT in late pregnancy. During the first few days of lactation, RT $(450 \mathrm{~min} / \mathrm{d})$ was reduced in cows with subclinical diseases or health disorders compared with cows that had mild inflammatory conditions and healthy cows or cows with only mild health disorders postpartum. Moreover, Siivonen et al. (2011) observed that cows with the strongest clinical signs of mastitis spent more time eating but less time ruminating and drinking. Pedersen (2010) reported that ketosis in early lactation was associated with high individual variability in RT, in agreement with our results, where groups of affected cows had greater SE values, indicative of higher variation among cows. A recent study (Liboreiro et al., 2015) presented a weak correlation between both calcium and nonesterified fatty acid concentrations and RT. In contrast, the repeated measures analysis of our data indicated a significant difference in RT between healthy cows and those with negative energy balance who calved in summer and in postpartum RT between healthy cows and cows with subclinical hypocalcemia who had winter calvings (Figure 3). A possible explanation for this discrepancy is the additional statistical power provided by this methodology, which includes multiple measures from each individual but also addresses the lack of independence among multiple data points within the same subject.

\section{CONCLUSIONS}

Our results indicated that differences in RT between healthy and sick cows were not consistent and depended on the particular disease present, the period relative to calving, and the season. The effect of heat stress on changes in the pattern of rumination around calving for sick cows depended on specific health disorders and metabolic conditions. During summer, but not winter, cows with negative energy balance and subclinical ketosis during early lactation had significantly lower RT both pre- and postpartum than cows without these disorders.

\section{ACKNOWLEDGMENTS}

The authors acknowledge the valuable assistance of University of Florida Dairy Unit personnel that collaborated during developing this study. We also acknowledge the support of SCR Engineers Ltd. (Netanya, Israel) for providing the rumination monitoring system used in this study.

\section{REFERENCES}

Aikman, P. C., C. K. Reynolds, and D. E. Beever. 2008. Diet digestibility, rate of passage, and eating and rumination behavior of Jersey and Holstein cows. J. Dairy Sci. 91:1103-1114.

Beauchemin, K. A. 1991. Ingestion and mastication of feed by dairy cattle. Vet. Clin. North Am. Food Anim. Pract. 7:439-463.

Beauchemin, K. A., and W. Z. Yang. 2005. Effects of physically effective fiber on intake, chewing activity, and ruminal acidosis for dairy cows fed diets based on corn silage. J. Dairy Sci. 88:2117-2129.

Benzaquen, M. E., C. A. Risco, L. F. Archbald, P. Melendez, M. J. Thatcher, and W. W. Tharcher. 2007. Rectal temperature, calving-related factors, and the incidence of puerperal metritis in postpartum dairy cows. J. Dairy Sci. 90:2804-2814.

Bohmanova, J., I. Misztal, and J. B. Cole. 2007. Temperature-humidity index as indicator of milk production losses due to heat stress. J. Dairy Sci. 90:1947-1956.

Braun, U., L. Trösch, F. Nydegger, and M. Hässig. 2013. Evaluation of eating and rumination behaviour in cows using a noseband pressure sensor. BMC Vet. Res. 9:164.

Burfeind, O., K. Schirmann, M. A. G. von Keyserlingk, D. M. Veira, D. M. Weary, and W. Heuwieser. 2011. Technical note: Evaluation of a system for monitoring rumination in heifers and calves. J. Dairy Sci. 94:426-430.

Burton, J. L., S. A. Madsen, L. C. Chang, P. S. Weber, K. R. Buckham, R. van Dorp, M. C. Hickey, and B. Earley. 2005. Gene expression signatures in neutrophils exposed to glucocorticoids: A new paradigm to help explain "neutrophil dysfunction" in parturient dairy cows. Vet. Immunol. Immunopathol. 105:197-219.

Byskov, M. V., E. Nadeau, B. E. O. Johansson, and P. Nørgaard. 2015. Variations in automatically recorded rumination time as explained by variations in intake of dietary fractions and milk production, and between-cow variation. J. Dairy Sci. 98:3926-3937.

Calamari, L., N. Soriani, G. Panella, F. Petrera, A. Minuti, and E. Trevisi. 2014. Rumination time around calving: An early signal to detect cows at greater risk of disease. J. Dairy Sci. 97:3635-3647.

Chapinal, N., M. Carson, T. F. Duffield, M. Capel, S. Godden, M. Overton, J. E. P. Santos, and S. J. LeBlanc. 2011. The association of serum metabolites with clinical disease during the transition period. J. Dairy Sci. 94:4897-4903. 
Clark, C. E., N. A. Lyons, L. Millapan, S. Talukder, G. M. Cronin, K. L. Kerrisk, and S. C. Garcia. 2015. Rumination and activity levels as predictors of calving for dairy cows. Animal 9:691-695.

de Vries, A., and C. A. Risco. 2005. Trends and seasonality of reproductive performance in Florida and Georgia dairy herds from 1976 to 2002. J. Dairy Sci. 88:3155-3165.

Dikmen, S., and P. J. Hansen. 2009. Is the temperature-humidity index the best indicator of heat stress in lactating dairy cows in a subtropical environment? J. Dairy Sci. 92:109-116.

Goff, J. P. 2004. Macromineral disorders of the transition cow. Vet. Clin. North Am. Food Anim. Pract. 20:471-494.

Hammon, D. S., I. M. Evjen, T. R. Dhiman, J. P. Goff, and J. L. Walters. 2006. Neutrophil function and energy status in Holstein cows with uterine health disorders. Vet. Immunol. Immunopathol. 113:21-29.

Herskin, M. S., L. Munksgaard, and J. Ladewig. 2004. Effects of acute stressors on nociception, adrenocortical responses and behavior of dairy cows. Physiol. Behav. 83:411-420.

Huzzey, J. M., M. A. G. von Keyserlingk, and D. M. Weary. 2005. Changes in feeding, drinking, and standing behavior of dairy cows during the transition period. J. Dairy Sci. 88:2454-2461.

Johnson, H. D., A. C. Ragsdale, I. L. Berry, and M. D. Shanklin. 1963 Temperature-humidity effects including influence of acclimation in feed and water consumption of Holstein cattle. Univ. Missouri Agric. Exp. Stn. Res. Bull. 846. Columbia.

Jordan, E. R. 2003. Effects of heat stress on reproduction. J. Dairy Sci. 86(E. Suppl.):E104-E114.

Kononoff, P. J., H. A. Lehman, and A. J. Heinrichs. 2002. Technical note-a comparison of methods used to measure eating and ruminating activity in confined dairy cattle. J. Dairy Sci. 85:1801-1803.

LeBlanc, S. 2010. Monitoring metabolic health of dairy cattle in the transition period. J. Reprod. Dev. 56(Suppl.):S29-S35.

LeBlanc, S. J., K. D. Lissemore, D. F. Kelton, T. F. Duffield, and K. E. Leslie. 2006. Major advances in disease prevention in dairy cattle. J. Dairy Sci. 89:1267-1279.

Liboreiro, D. N., K. S. Machado, P. R. Silva, M. M. Maturana, T. K. Nishimura, A. P. Brandão, M. I. Endres, and R. C. Chebel. 2015. Characterization of peripartum rumination and activity of cows diagnosed with metabolic and uterine diseases. J. Dairy Sci. 98:6812-6827.

NRC (National Research Council). 2001. Nutrient Requirements of Dairy Cattle. 7th rev. ed. Natl. Acad. Sci., Washington, DC.
Ospina, P. A., D. V. Nydam, T. Stokol, and T. R. Overton. 2010 Evaluation of nonesterified fatty acids and $\beta$-hydroxybutyrate in transition dairy cattle in the northeastern United States: Critical thresholds for prediction of clinical diseases. J. Dairy Sci. 93:546554 .

Pahl, C., E. Hartung, A. Grothmann, K. Mahlkow-Nerge, and A. Haeussermann. 2014. Rumination activity of dairy cows in the 24 hours before and after calving. J. Dairy Sci. 97:6935-6941.

Pedersen, A. 2010. Rumination measurements and ketosis in early lactation. Dansk Veterinaertidsskrift. 93:28-32.

Schirmann, K., N. Chapinal, D. M. Weary, L. Vickers, and M. A. G. von Keyserlingk. 2013. Short communication: Rumination and feeding behavior before and after calving in dairy cows. J. Dairy Sci. 96:7088-7092.

Schirmann, K., M. A. G. von Keyserlingk, D. M. Weary, D. M. Veira, and W. Heuwieser. 2009. Technical note: Validation of a system for monitoring rumination in dairy cows. J. Dairy Sci. 92:6052-6055.

Siivonen, J., S. Taponen, M. Hovinen, M. Pastell, B. J. Lensink, S. Pyörälä, and L. Hänninen. 2011. Impact of acute clinical mastitis on cow behaviour. Appl. Anim. Behav. Sci. 132:101-106.

Soriani, N., G. Panella, and L. Calamari. 2013. Rumination time during the summer season and its relationships with metabolic conditions and milk production. J. Dairy Sci. 96:5082-5094.

Soriani, N., E. Trevisi, and L. Calamari. 2012. Relationships between rumination time, metabolic conditions, and health status in dairy cows during the transition period. J. Anim. Sci. 90:4544-4554.

St-Pierre, N. R., B. Cobanov, and G. Schnitkey. 2003. Economic losses from heat stress by US livestock industries. J. Dairy Sci. 86(E. Suppl.):E52-E77.

Vergara, C. F., D. Dopfer, N. B. Cook, K. V. Norlund, J. A. A. McArt, D. V. Nydam, and G. R. Oetzel. 2014. Risk factors for postpartum problems in dairy cows: Explanatory and predictive modeling. J. Dairy Sci. 97:4127-4140.

Weather Underground. 2014. Accessed October 2014. http://www. wunderground.com.

Welch, J. G., and A. M. Smith. 1970. Forage quality and rumination time in cattle. J. Dairy Sci. 53:797-800.

Welch, J. G., and A. M. Smith. 1972. Milk fat depression and rumination stimulation. J. Dairy Sci. 58:678-681.

West, J. W. 2003. Effects of heat-stress on production in dairy cattle. J. Dairy Sci. 86:2131-2144. 